\title{
O MOTIVO DA METAMORFOSE EM FRANZ KAFKA
}

\section{THE METAMORPHOSIS MOTIF IN THE NOVEL OF FRANZ KAFKA}

\author{
Francisco Elias Simão MERÇON \\ USP - Universidade de São Paulo \\ CNPQ
}

\begin{abstract}
RESUMO: As definições do lexema "metamorfose" já são por si só semioticamente instigantes. Seja num nível mais figurativo, como "mudança completa de forma", "mudança de aparência, de caráter", seja num nível mais profundo, como "mudança de natureza", que parece colocar em questão a própria identidade da grandeza que sofre a transformação, a metamorfose se revela como um fenômeno instrutivo do modo como opera a significação em seus diferentes estratos. Muito comum ao universo mítico e ao campo da biologia, recebe ainda tratamento todo particular na obra A metamorfose (1997), de Franz Kafka, pois que concede aí uma significativa importância ao andamento que preside o fenômeno: é que, não bastasse a tensão causada pela constituição modal-concessiva da transmutação do homem em inseto, há uma desarmonia inerente ao fenômeno na medida em que a metamorfose corporal e sensorial de Gregor foi mais veloz que a metamorfose intelectual. Além disso, o motivo da metamorfose é, em Kafka, tipificado por uma problemática de ordem fenomenológica: quais modalidades estão presentes no ato de consciência de Grete, a irmã de Gregor, quando ela emite um juízo acerca do irmão?
\end{abstract}

PALAVRAS-CHAVE: Motivo; Metamorfose; Franz Kafka; Modalidade Epistêmica; Modalidade Alética.

ABSTRACT: The definitions of the lexeme "metamorphosis" are in itself semiotically gripping. Whether in a more figurative level, as "complete change of shape", as "change in appearance, character" or in a deeper level, such as "change of nature" which seems to throw doubt in the very identity of the entity which is subjected to the transformation, the metamorphosis is revealed as an instructive phenomenon of the way how the significance operates in its different strata. Very common to the mythical world and the realm of biology, it still receives a particular facet in the Franz Kafka's work The metamorphosis (1997), as a result of the significant importance given to the tempo that rules the phenomenon: not enough the tension caused by the modal concessive constitution of the transmutation of man into an insect, there is a disharmony intrinsic to the phenomenon, inasmuch as the bodily and sensory metamorphosis of Gregor was faster than the intellectual one. Furthermore, the metamorphosis motif is thus typified by a problem of phenomenological nature: what modal arrangements are in the act of Grete's consciousness when she makes a judgment about her brother?

KEYWORDS: Motif; Metamorphosis; Franz Kafka; Epistemic Modality; Alethiological Modality. 
CASA, Vol.8 n.2, dezembro de 2010

\section{Introdução}

[...] a metamorfose, de um modo geral, implica destruição, ou melhor, desconstrução de uma forma anterior, que não desaparece totalmente. Dela ficam traços na forma nova [...]

Ignacio Assis Silva

Um exame das ocorrências, no discurso literário, de diferentes tipos de transformação atorial que opera na dimensão figurativa do ator nos leva a considerar a possibilidade de existência do motivo da "metamorfose". Ultrapassa-se, assim, um tipo de reflexão temática acerca desse fenômeno, de ordem mais especulativa, para investigá-lo a partir do ponto de vista semiótico. Especificamente na novela de Kafka, A metamorfose, o motivo da metamorfose suscita ainda questões acerca do espaço modal da enunciação ao revelar a presença de diferentes instâncias - a saber, cognitiva, perceptiva e afetiva -, cooperando na constituição do objeto semiótico. Os pontos de inflexão fenomenológica da semiótica estão aí postos nos seguintes termos: o corpo é uma instância que se projeta para fora, para o seu entorno, de diferentes modos a partir dos mais variados atos. O motivo da metamorfose apresentado por Kafka sugere-nos uma pista desse instigante movimento de problemática semiofenomenológica.

\section{A possibilidade da metamorfose como motivo}

O motivo é uma unidade discursiva perceptível em sua dimensão figurativa e possui "um sentido independente de sua significação funcional em relação ao conjunto da narrativa em que se encontra" (GREIMAS; COURTÉS, [1983], p. 290). Além disso, o motivo é normalmente englobado por uma configuração discursiva maior da qual ele se destaca. Essa definição discursivo-semiológica do conceito abre a possibilidade de investigar as ocorrências do motivo fora do campo discursivo dos estudos do mito e da etnoliteratura, o que reforça ainda mais o seu caráter migratório. De fato, trata-se de uma configuração discursiva que parece ter vida própria, migrando não apenas de uma a outra narrativa pertencente a um mesmo universo cultural, mas também o ultrapassando ao migrar "até mesmo para fora dos limites de uma área cultural" (GREIMAS; COURTÉS, [1983], p. 290). Um mesmo motivo pode também ocorrer em textos distantes temporalmente e em gêneros discursivos distintos, como teremos a oportunidade de mostrar a seguir em alguns exemplos que escolhemos de configurações discursivas que caracterizam o fenômeno da metamorfose.

De um modo geral, as literaturas que versam sobre o fenômeno da metamorfose tratam-na normalmente como decorrente de fenômenos naturais, tal qual a lagarta que vira borboleta, como uma transformação operada por um sujeito criador (cujo caso mais famoso talvez seja o de Frankenstein), ou, ainda, por meio de uma mediação transcendente (como acontece nas cosmogonias). Frequentemente apresentadas também como transformação do homem em animal, as metamorfoses eram marcadas como punição. Um exemplo clássico desse tipo pode ser visto na obra do poeta romano Ovídio, Metamorfoses (2000):

[...] e como serpente eis que se alonga, Eis na cútis nascer vê dura escama, Cerúleas nódoas variar-lhe o corpo: Na terra cai de peitos: manso, e manso 
Os membros se confundem, que o sustinham, E em buliçosa cauda se afeiçoam (p. 75).

A esse pequeno trecho segue o momento de desespero da esposa de Cadmo ao se deparar com o marido transformado em serpente:

Coa mão ferindo o peito, a esposa clama: "Cadmo, espera; infeliz, despe esse monstro! Que é isto! Que é dos ombros, que é dos braços! As mãos, os pés, e a cor, e o resto, e tudo! Por que, poder do Céu, por que, Destinos, Me não mudais também na forma horrenda?" (idem, ibidem, p. 75).

Diante do marido desgraçado, a esposa apela ao "poder do Céu" para que a transforme também em uma "forma horrenda". Trata-se visivelmente de um poder sobrenatural ("numes"), tal como o próprio Cadmo denomina: "[...] imploro aos numes/ Que em comprida serpente me transformem". A sanção, nesse caso, decorre do desafio de Cadmo, feito aos numes, depois de ter matado uma serpente.

Em todos esses casos, a metamorfose apresenta uma forma discursivosemiótica que a caracteriza como motivo. Trata-se efetivamente de uma configuração discursiva que se destaca de outra, de maior dimensão, que a engloba. E a mudança de forma que distingue o fenômeno se opera, em todos os casos, em sua dimensão figurativa. Outro aspecto do motivo que os exemplos apresentados revelam é que o fenômeno da metamorfose se mostra como sendo uma unidade figurativa invariante, independente da variação temática que lhe é subjacente em cada uma das obras mencionadas.

\section{2. $O$ acontecimento e o excedente de sentido}

A partir dos exemplos de metamorfoses rapidamente apresentados na seção anterior é possível extrair algumas conclusões importantes para darmos o devido prosseguimento às nossas reflexões. É que, à exceção da ocorrência em Kafka, o fenômeno da metamorfose apresenta um forte vínculo causal com a narrativa que o engloba. A presença do motivo se justifica, nesse caso, por programas narrativos e actantes bem determinados. Normalmente, esse vínculo tem como peça fundamental o actante destinador - seja ele o destinador julgador, seja uma espécie de destinador transcendente, natural (como no caso da largada que se transforma em borboleta) ou sobrenatural (como no caso da transformação de Cadmo numa serpente), que age como operador da transformação -, mas o importante é a ênfase dada à relação de causalidade que está implicada na lógica do fenômeno.

Há, portanto, um procedimento discursivo específico que vincula o motivo à configuração discursiva maior que o engloba. No caso da narrativa de Kafka, também há, em certo sentido, algum tipo de vínculo, mas com uma crucial particularidade que a distingue das outras narrativas. Na metamorfose de Gregor, não há um actante operador da transformação, ou mesmo uma causa que pudesse justificá-la. De modo bastante diverso, Gregor Samsa, o protagonista da Metamorfose, não desafia nenhum Deus, cujo poder se exerceria com a sua transformação em inseto; é num simples acordar que Gregor se encontra metamorfoseado. Esse misterioso evento, a princípio intrigante, revela uma maior preocupação do enunciador com o próprio fenômeno e, também, em mostrar mais as consequências da metamorfose do que a sua causa.

Outro fato que distingue o motivo da metamorfose de Gregor é o universo em que ocorre o fenômeno. Nele não há seres fabulares, o espaço não é um espaço afastado do lar, onde o herói se encontra frequentemente desprotegido para lutar contra as forças 
antagônicas pelas quais é ameaçado. Enfim, não se trata também de um universo mítico. Tudo ocorre em meio ao próprio ambiente do personagem, mais exatamente em seu próprio quarto, incidindo no cotidiano de uma família pequeno-burguesa. A metamorfose de Gregor se passa num mundo moderno e burocrático, em que o herói é um trabalhador assalariado cuja vida consiste em acordar cedo todos os dias, numa rotina de trabalho e viagens estafante.

Além disso, ela é introduzida na história por uma operação modal-concessiva. A discursivização da novela de Kafka se mostra descontínua, sobretudo porque a história tem início não com uma introdução no sentido estrito da palavra. Com efeito, sem qualquer delonga ou preparação gradativa tipificada nas narrativas de "Era uma vez...", nas primeiras linhas da novela, o enunciador apresenta a subitaneidade do insólito acontecimento que irrompe no cotidiano da família Samsa:

Quando certa manhã Gregor Samsa acordou de sonhos intranquilos, encontrou-se em sua cama metamorfoseado num inseto monstruoso (KAFKA, 1997, p. 7).

A irrupção desse acontecimento imprevisível transgride a lógica do bom senso - e até mesmo a lógica natural da condição humana -, que afasta qualquer possibilidade de o ser humano acordar metamorfoseado em inseto. O caráter contingencial da metamorfose de Gregor vai resultar, posteriormente, na dificuldade do enunciador em ajustar esse corpo estranho (o "inseto monstruoso") sintagmática e paradigmaticamente à cadeia do cotidiano dos Samsa. Em outras palavras, o problema levantado pelo enunciador kafkiano reside em saber à qual paradigma e à qual posição na cadeia sintagmática se ajusta Gregor depois da metamorfose. A iminente irrupção do "inseto monstruoso" no campo de percepção da família Samsa torna-se um excedente de sentido na vida rotineira dos Samsa. Trata-se, portanto, de fenômeno característico do acontecimento. Ao contrário do cotidiano, o acontecimento é originalmente uma ocorrência da ordem do sobrevir, de caráter inesperado, que transgride todas as previsibilidades do sujeito que "se vê lançado longe de suas vias habituais e projetado em sua devastação":

Segundo o Micro-Robert, o acontecimento é definido como "o que chega e que tem importância para o homem". A primeira indicação é mais compreensível que a segunda, pois que ela é da ordem do sobrevir, da imprevisibilidade, isto é, o tempo mais vivo que o homem poderia sofrer. A segunda indicação, "e que tem importância para o homem", concerne à tonicidade, na medida em que esta última é a modalidade humana por excelência, aquela que fixa o próprio estado do sujeito de estado. O sujeito instalado na ordem racional, programado e "partidário" do pervir, controlador de suas expectativas sucessivas, se vê lançado longe de suas vias habituais e projetado em sua devastação [...] (ZILBERBERG, 2002, p. 140).

A irrupção de um acontecimento não pode prescindir, em sua essência, de reações de ordem afetiva naqueles que o experimentam. As noções de "energia" ou de "tensão" que subjazem à noção de "afeto" são forte indício de que os coeficientes tensivos da tonicidade e sobretudo do andamento têm extrema relevância para a compreensão do acontecimento. Segundo a observação feita por Zilberberg, não há como não falar de andamento quando se trata de abordar questões em torno da noção de acontecimento: 
O andamento é o senhor tanto dos nossos pensamentos como dos nossos afetos, pois ele controla despoticamente os aumentos e as diminuições constitutivas de nossas vivências. Não é, entretanto, a existência do andamento que está em causa, e sim sua autoridade: como instituir os rudimentos de uma semiótica do acontecimento sem declarar a prevalência do andamento? (ZILBERBERG, 2002, p. 114).

A metamorfose do homem em inseto infringe a lógica do senso comum. Em razão do hábito de associar percepções sucessivas colhidas da experiência estabelecendo entre elas uma relação causal, o leitor se surpreende diante da impossibilidade de se apoiar a um antecedente que se assemelhe a esse insólito acontecimento. A metamorfose de Gregor surge como um acontecimento da ordem do absurdo, em que o impensável acontece, que traz em si uma constituição modal-concessiva ao apresentar um dado programa narrativo como irrealizável (não poder ser) e um contraprograma que, no entanto, garante a sua realização (poder ser). O caráter concessivo do fenômeno da metamorfose pode ser ainda resumido no seguinte enunciado: embora parecesse impossível tal metamorfose, ela aconteceu.

Essas observações revelam a existência de dois distintos mecanismos discursivos internos que controlam essas ocorrências de configurações discursivas que se destacam da configuração isotópica geral do texto. São mecanismos que supõem duas instâncias enunciativas de ordem distinta: uma instância insere o motivo com vínculo lógicosintático da ordem da implicação, por isso, dentro de um quadro de possibilidades da ocorrência do fenômeno que, de algum modo, é explicado; a outra instância o insere sob a ordem da concessividade, ou seja, fora do quadro de qualquer possibilidade de ocorrência de um fenômeno de tal natureza. Além disso, enquanto uma instância busca apresentar possíveis causas para o fenômeno, a outra se preocupa com os modos de presença do fenômeno. De fato, à exceção da metamorfose de Gregor, as outras metamorfoses são previstas pelo próprio universo discursivo do qual elas fazem parte, por exemplo, o universo mítico em Ovídio; ou porque, no romance Frankenstein (1818), de Mary Shelley, são justificadas pelos conhecimentos de ciência experimental do personagem, estudante de medicina, Victor Frankenstein ${ }^{1}$. Em todos esses casos, há um actante que justifica a introdução dessa configuração discursiva estranha na economia geral do texto. Mesmo se considerássemos a metamorfose da lagarta em borboleta, o princípio motor da transformação poderia ser facilmente explicado pelo discurso científico. O narrador kafkiano, por sua vez, ignora as causas da metamorfose e a apresenta como fenômeno e experiência vivida, ou seja, em constituição.

Se considerarmos, então, esses textos como objetos modais da ordem do fazer saber acerca do fenômeno e como responsáveis pela atualização do motivo da metamorfose, podemos estabelecer uma distinção entre, de um lado, um saber causal - que corresponde às narrativas que englobam o motivo pelas vias da causalidade - e, de outro, um saber modalconcessivo que corresponde à narrativa de Kafka, em que a metamorfose é apresentada sem pressuposição existencial, como um objeto semiótico que apresenta um excedente de sentido e, por isso, em vias de constituição no espaço modal de uma enunciação.

\footnotetext{
${ }^{1}$ Podemos mencionar, ainda, o romance Dr. Jekyll e Mr. Hyde, de Stevenson, em que a transformação é justificada, na história, pelos experimentos bioquímicos do Dr. Jekyll.
} 


\section{Pressupostos fenomenológicos da significação}

Ao abrir mão das causas da metamorfose para se preocupar com os modos de constituição do fenômeno, a instância enunciativa kafkiana deixa ressoar fortes os pressupostos fenomenológicos presentes no processo da significação. Para aquele que se coloca no mundo ao modo do sujeito que vive num realismo ingênuo, a problemática que atravessa percepção, significação e linguagem não tem muita pertinência. Nesse caso, os atos de perceber e significar, se não estão totalmente fundados num universo de sentido estável, visam, em todo o caso, à estabilidade do senso comum. A importância dada a essa estabilidade fica também evidente quando examinamos os textos míticos, folclóricos, as fábulas, as lendas, ou seja, os textos dos universos discursivos assentes numa tradição popular. As metamorfoses que daí se sobressaem, se por um lado trazem em si a dramaticidade característica dos mitos, por outro, são vividas pelos habitantes desse mundo mítico como experiência familiar, não causando problemas de ordem modal-cognitiva aos sujeitos que nele habitam.

No trecho das Metamorfoses (2000), de Ovídio (já citado anteriormente na primeira seção do presente artigo), em que a esposa de Cadmo presencia a metamorfose do marido em serpente, o desespero da esposa é por ela não aceitar a punição que os deuses infligem ao marido. Quanto ao próprio fenômeno da metamorfose, ela não o questiona, uma vez que é previsto naquele universo cujas leis cosmogônicas outorgam aos deuses tais poderes extra-humanos. Assim, de acordo com o simulacro de mundo aí representado, não se questiona a crença sobre a experiência da metamorfose, uma vez que a causa divina lhe garante a existência.

Na novela de Kafka, há um deslocamento de toda a problemática, mesmo que não haja aí um longo questionamento explícito acerca do fenômeno. Na verdade, há um momento em que o próprio Gregor questiona o ocorrido: "- O que aconteceu comigo? pensou" (KAFKA, 1997, p. 7). Embora discreto, esse pequeno trecho traz a significação do texto claramente para uma problemática de ordem fenomenológica. De fato, o estranhamento causado pelo próprio corpo metamorfoseado num inseto revela a presença de um excesso de significação que escapa à percepção habitual, e, por isso, ele não compreende o que lhe ocorre. É como se houvesse em Gregor o estranhamento decorrente de um acontecimento cuja velocidade ultrapassasse as suas expectativas. Não podemos, no entanto, deixar de reconhecer aí uma cisão que opera no sujeito, entre, de um lado, o sujeito que pensa e, de outro, o sujeito que sente. Assim, a reflexão do sujeito que ainda pensa como humano, e por isso pode se questionar "- O que aconteceu comigo?" (KAFKA, 1997, p. 7), distingue-se claramente da percepção sensorial de seu corpo que sofre a alteração decorrente da transformação em inseto. Essa desarmonia entre o sujeito que pensa como homem e o sujeito que percebe como inseto se justifica plenamente, na medida em que a metamorfose corporal e sensorial foi bem mais veloz que a intelectual. Um fato, talvez, que possa parecer dissimular a problemática fenomenológica presente na metamorfose de Gregor é a naturalidade aparente com que, depois, seus familiares, e também o próprio Gregor, passam a vivenciar essa experiência ${ }^{2}$. Mas isso em nada lhe retira a inflexão fenomenológica da transformação.

Os termos "significação" e "percepção" estiveram presentes constantemente nas reflexões dos fenomenólogos Edmund Husserl e Maurice Merleau-Ponty, mas também nas de A. J. Greimas e outros semioticistas como Jacques Fontanille, Claude Zilberberg,

\footnotetext{
${ }^{2}$ Camus, em seu ensaio intitulado "A esperança e o absurdo na obra de Franz Kafka" já chamava a atenção para um paradoxo recorrente na obra de Kafka, decorrente da naturalidade com que os personagens kafkianos vivenciam experiências de caráter insólito (CAMUS, 2005, p. 146).
} 
Herman Parret, Jean-Claude Coquet, Eric Landowski, entre outros. Já em Sémantique structurale, obra publicada em 1966, Greimas lembra que o interesse dado à percepção é uma atitude epistemológica comum às ciências humanas do século XX. Segundo ele, "a explicação dos fatos estéticos se situa mais ao nível da percepção da obra, e não mais da exploração do gênio ou da imaginação" (GREIMAS, [1966] 2007, p. 7). Mas esse importante papel da percepção é fruto de uma transformação mais profunda por que passaram as ciências humanas nesse período de meados do século XX, quando se buscava encontrar uma terceira via metodológica que conciliasse uma abordagem tanto quantitativa quanto qualitativa na investigação das significações do mundo humano.

Era um período de crise das ciências humanas no Ocidente ${ }^{3}$, marcado por um paradigma que polarizava os saberes entre, de um lado, o objetivismo-naturalista e, de outro, o subjetivista-transcendental herdado do pensamento moderno, sobretudo de Descartes. A crítica de Husserl era dirigida ao imperialismo objetivo-naturalista que contaminava as ciências humanas, pretendendo, com isso, elevar a sua condição de ciência. Husserl apontara até mesmo um grave erro epistemológico do naturalismo, que se empenhava, de modo equívoco e ilegítimo, em naturalizar as leis e os princípios ideal-lógicos para fundá-los a partir dos fatos. Parte desses problemas já havia sido denunciada por Husserl, em 1913, quando de sua obra Prolegômenos à lógica pura, em que criticara duramente o filósofo Stuart Mill ao tentar fundar leis lógicas (no caso, a lei da contradição) a partir de fatos (HUSSERL, [1913] 2002, § 25 e 26). Mas é com Merleau-Ponty, mais propriamente nas duas teses Estrutura do comportamento e Fenomenologia da percepção, que surgiram as críticas mais duras aos modelos reducionistas comuns à ciência de sua época. Esse reducionismo apontado pelo filósofo francês ficava ainda mais evidente quando as ciências se voltavam para o entendimento do corpo e da linguagem. Em Fenomenologia da percepção ([1945] 1999), mais propriamente no capítulo "O corpo como expressão e a fala", o filósofo expõe a insuficiência dos modelos empiristas e intelectualistas na compreensão da linguagem, os quais ele considerava extremamente reducionistas em suas investigações.

O que caracteriza um objeto científico, segundo Merleau-Ponty, é o fato de sua constituição ser decorrente de um processo de redução do objeto de investigação. A maior crítica do filósofo era de que esse modo reducionista, talvez necessário para a compreensão de alguns objetos, se tornava perigoso quando aplicado ao conhecimento do corpo, pois que se perdia aí, depois de operada a redução, parte importante do objeto ([1945] 1999, p. 111). Mais exatamente, perdia-se do corpo o seu poder de significação. E essa perda era irreparável aos olhos do filósofo. É importante ressaltar aqui que essa objetividade mecanicista e reducionista que se operava na construção do objeto científico não reconhecia um traço imprescindível ao corpo: a intencionalidade, ou seja, sua capacidade de se dirigir sempre para fora de si de maneira a constituir-se de modo significativo com e no mundo.

$\mathrm{O}$ que Merleau-Ponty queria era fundar uma subjetividade no corpo, e não mais na razão. Percebe-se aí a retomada de uma questão colocada por Husserl quando apontava a crise nas ciências humanas, por tentarem, à maneira das ciências exatas, construir suas bases sobre os fatos, e não, como defendia o filósofo alemão, a partir de normas bem estabelecidas. Essas reflexões de Merleau-Ponty sobre as consequências desastrosas desse reducionismo que ele apontara na constituição do objeto científico se aplicavam também aos estudos da linguagem. Talvez pela sua forte inclinação às artes, Merleau-Ponty se interessara pela linguagem e pela significação. É justamente numa compreensão da linguagem como

\footnotetext{
${ }^{3}$ Em 1936, Husserl já denunciara essa crise, questionando o fracasso das ciências no Ocidente que tentaram erroneamente fundar as ciências do espírito em bases objetivas, tal fora feito com as ciências da natureza (HUSSERL, 2008, p. 63-64).
} 
intencionalidade expressiva do corpo que o filósofo vai denunciar a dicotomia clássica entre sujeito e objeto, procurando a todo custo ultrapassá-la.

Merleau-Ponty constata que a concepção de linguagem como região fundante é tardia ([1945] 1999, p. 237). Isso porque a linguagem sempre foi relegada a segundo plano. É preciso lembrar que, ao longo da história da cultura ocidental, esse desinteresse pela linguagem ocorreu de maneiras diferentes, entre as quais podemos destacar dois grandes períodos representativos dessa história: a época clássica, que valorizava o discurso representacional, relegando a linguagem ao esquecimento; e a época moderna, especialmente com Descartes, em que a linguagem fica a serviço do cogito, do qual ela é objeto e instrumento ${ }^{4}$. Mas a crítica de Merleau-Ponty é direcionada a um período mais recente, representado por duas grandes correntes de pensamento, o empirismo e o intelectualismo. De um modo geral, esse reducionismo era apresentado nos seguintes termos:

E todavia as duas concepções coincidem em que tanto para uma como para a outra a palavra não tem significação. Isso é evidente na primeira [na tese empirista], já que a evocação da palavra não é mediada por nenhum conceito, que os estímulos ou os "estados de consciência" dados a convocam segundo leis da mecânica nervosa ou segundo leis da associação, e que assim a palavra não traz seu sentido, não tem nenhuma potência interior e é apenas um fenômeno psíquico, fisiológico ou mesmo físico [...]. O mesmo acontece quando se duplica a denominação com uma operação categorial. A palavra ainda está desprovida de uma eficácia própria, desta vez porque é apenas o signo exterior de um reconhecimento interior que poderia fazer-se sem ela e para o qual ela não contribui. A palavra não é desprovida de sentido, já que atrás dela existe uma operação categorial, mas ela não tem esse sentido, não o possui; é o pensamento que tem um sentido, e a palavra continua a ser um invólucro vazio. [...] $\mathrm{Na}$ primeira concepção [tese empirista], estamos aquém da linguagem enquanto significativa; na segunda [tese intelectualista], estamos além - na primeira, não há ninguém que fale, na segunda, há o sujeito, mas ele não é um sujeito falante, é o sujeito pensante (MERLEAU-PONTY, [1945] 1999, p. 240-241).

As questões que incomodavam o filósofo nas teses empiristas e intelectualistas, que ele considerava reducionistas, parecem ter encontrado uma solução quando Merleau-Ponty reconhece a existência de um sentido próprio à expressão gestual da fala que, tal como a ideia de corpo, ultrapassa a dicotomia clássica que opunha sujeito a objeto. A linguagem, nesse caso, "não é mais um meio, ela é uma manifestação, uma revelação do ser íntimo e do elo psíquico que nos une ao mundo e aos nossos semelhantes" (GOLDSTEIN apud MERLEAU-PONTY, [1945] 1999, p. 266). A expressão da linguagem, aqui, encenaria a nossa relação como o mundo. Talvez tenha sido essa importância dada à expressão como lugar de manifestação do sentido que chamara a atenção de Greimas, em suas primeiras reflexões, para a fenomenologia já em sua primeira obra, Sémantique structurale. Quanto à retomada das questões de pertinência fenomenológica pela semiótica, ela se fez principalmente partir da década de 1990, ou seja, pouco depois da publicação do livro $D a$

\footnotetext{
${ }^{4}$ Para aprofundamento acerca desse desinteresse pela linguagem, ver o artigo "La sémiotique transcendental et les paradigmes de la Prima Philosophia", de Karl Otto Apel, em Revue de Métaphysique et de Morale, 92e. Année, n. 2, Avril-Juin, Paris, Armand Colin, p. 147-163.
} 
imperfeição, de Greimas, que saiu em 1987 na França 5 . Atualmente, uma pergunta que se faz quando, ao modo da fenomenologia, se investiga em semiótica o universo de significação do sensível, e do corpo, é se essa conduta, se levada às últimas consequências, nos levaria a abandonar as bases epistemologias saussurianas e hjelmslevianas em pelo menos dois pontos, o princípio da diferença e o da imanência. De uma maneira indireta, essa questão revela uma suspeita sobre essa vizinhança epistêmica entre a semiótica e a fenomenologia. Alguns teóricos já manifestaram mais abertamente essa suspeita, como é caso de Claude Zilberberg, que, na Introdução de seu livro Eléments de grammaire tensive (2006), faz a seguinte observação:

Efetiva ou não, justificada ou não, essa "virada fenomenológica" constitui uma intimação. Fazendo suas as posições da fenomenologia, e em especial da que se configura na obra de Merleau-Ponty, não estaria a semiótica se afastando de sua dupla referência saussuriana e hjelmsleviana? Em caso afirmativo, não poderíamos considerar que, "desgastado", o concebido se retira perante o "frescor" do percebido? Deixamos de lado aqui a questão de saber se uma disciplina exigente pode trocar de base conceitual sem que isso acarrete importantes consequências (p. 8) ${ }^{6}$.

No trecho acima, a questão posta por Zilberberg, que indaga se, desgastado, "o concebido se retira perante o "frescor' do percebido" traz certa ambiguidade, pois revela a novidade da fenomenologia ao se debruçar sobre um universo que ultrapassa o terreno do concebido ao mesmo tempo que, de modo sutilmente irônico, parece insinuar um possível modismo caracterizado pelo "frescor" dessa presença fenomenológica no âmbito da semiótica. Acreditamos, no entanto, que essa aproximação seja profícua para os estudos da significação, afinal não é novidade que a semiótica se valeu, ao longo de curta história, de outras importantes vizinhanças. Entre elas, destacamos algumas mais próximas, como a linguística saussuriana, a linguística da enunciação e a antropologia cultural (Cf. BERTRAND, 2003, p. 17-18). Mas também outras não menos importantes, como a lógica e a matemática, que se fazem entrever na constituição do quadrado semiótico (constituinte do nível epistêmico da teoria) e na noção de função, cunhada por Hjelmslev (Cf. GREIMAS, [1983], p. 199) para fortalecer os princípios de relação e dependência, fazendo, com isso, alguns pequenos ajustes no quadro epistêmico da linguística saussuriana.

Obviamente não se sabe ao certo o quanto de toda essa problemática fenomenológica, da qual apresentamos apenas uma pequena parte, estava implícita na reflexão de Greimas, quando ele diz, em Sémantique structurale, que é "com conhecimento de causa que propomos considerar a percepção como sendo o lugar não linguístico onde se situa a apreensão da significação" (GREIMAS, [1966] 2007, p. 8). No entanto, na medida em que fornecem subsídios teóricos para refletir sobre o processo de significação de textos como, por exemplo, A metamorfose, as reflexões fenomenológicas podem futuramente vir a

\footnotetext{
5 A referência completa é: Algirdas Julien Greimas, De l’imperfecion, Périgueux, Pierre Fanlac, 1987. Há, também, uma tradução para o português: Algirdas Julien Greimas, Da imperfeição, São Paulo, Hackers Editores, 2002.

${ }^{6}$ Utilizamos, aqui, a tradução feita por Waldir Beividas no artigo de sua autoria intitulado "A dimensão do afeto em semiótica: entre fenomenologia e semiologia", a ser publicado em breve. Nesse texto, Beividas faz considerações de grande interesse epistemológico para o semioticista que se interessar por esse tipo de reflexão. O leitor poderá encontrar nele um exame minucioso de vários problemas que podem acarretar essa "virada fenomenológica", e, por meio de uma reflexão crítica impulsionada pela noção de "semiocepção", lança uma tese fortíssima acerca dos fundamentos primeiros da significação.
} 
contribuir em muito para se aprimorar na semiótica as ferramentas de análise para esse tipo de problema. O parti pris semiofenomenológico da significação parece, então, ser possível quando o objeto semiótico é apresentado com um excedente de significação que nos escapa à compreensão imediata ao ser introduzido abruptamente na economia do texto, comportamento temporal típico dos fenômenos de acontecimento que se antecipam ao nosso ritmo habitual.

\section{Do improvável ao necessário}

Como dissemos anteriormente, há uma desarmonia inerente à metamorfose de Gregor, na medida em que a transformação corporal foi mais rápida que a intelectual e a sensório-perceptiva. A descrição de seu corpo, já no primeiro parágrafo da novela, se assemelha ao que poderia ser de fato um inseto:

Quando certa manhã Gregor Samsa acordou de sonhos intranquilos, encontrou-se em sua cama metamorfoseado num inseto monstruoso. Estava deitado sobre suas costas duras como couraça e, ao levantar um pouco a cabeça, viu seu ventre abaulado, marrom, dividido por nervuras arqueadas, no topo do qual [do ventre] a coberta, prestes a deslizar de vez, ainda mal se sustinha. Suas numerosas pernas, lastimavelmente finas em comparação com o volume do resto do corpo, tremulavam desamparadas diante de seus olhos (KAFKA, 1997, p. 7).

Mas, ao longo da história, damos-nos conta de que não houve propriamente uma substituição imediata de identidade, permanecendo, ao contrário, uma situação ambígua que pode ser sintetizada da seguinte maneira: apesar de já inseto, é ainda Gregor. É que, como bem observou Ignacio Assis Silva, "a metamorfose, de um modo geral, implica destruição, ou melhor, desconstrução de uma forma anterior, que não desaparece totalmente. Dela ficam traços na forma nova [...]" (SILVA, 1995, p. 31-32). Isso significa que somente aos poucos a identidade de Gregor vai sendo substituída pelo inseto mediante um procedimento discursivo que vai inserindo aqui e ali, no texto, figuras sêmicas responsáveis pela construção figurativa do inseto, ao mesmo tempo em que vai extraindo gradativamente aqueles semas mobilizados na construção atorial de Gregor. Há uma passagem que mostra esses dois procedimentos discursivos atuando, um na construção do inseto, outro na desconstrução do humano. Deitado na cama, refletindo sobre a vida atribulada que levava na profissão de caixeiro-viajante, Gregor sente "uma leve coceira na parte de cima do ventre; [...] encontrou o lugar onde estava coçando, ocupado por uma porção de pontinhos brancos que não soube avaliar" (KAFKA, 1997, p. 8). Logo em seguida, ao observar o despertador sobre o armário, constatou que provavelmente não ouvira soar o alarme:

- Pai do céu! - pensou. Eram seis e meia e os ponteiros avançavam calmamente, passava até da meia hora, já se aproximava de um quarto. Será que o despertador não havia tocado? Via-se da cama que ele estava ajustado certo para quatro horas: seguramente o alarme tinha soado. Sim - mas era possível continuar dormindo tranquilo com esse toque de abalar a mobília? (KAFKA, 1997, p. 9-10).

No primeiro trecho que acabamos de mencionar, o ventre humano é substituído pelo ventre de inseto, "ocupado por uma porção de pontinhos brancos". No segundo, Gregor dá indícios de sofrer alteração na percepção auditiva quando se dá conta de que não ouvira o 
alarme do relógio. Em outra passagem, notamos, ao mesmo tempo, a presença de um novo traço dessa sobreposição gradual do inseto em Gregor e a alteração da percepção auditiva. Trata-se do momento em que, primeiro, ele ouve a voz de sua mãe chamando-o do lado de fora do quarto, e depois sua própria voz:

Que voz suave! Gregor se assustou quando ouviu sua própria voz responder, era inconfundivelmente a voz antiga, mas nela se imiscuía, como se viesse de baixo, um pipilar irreprimível de doloroso, que só no primeiro momento mantinha literal a clareza das palavras, para destruí-las de tal forma quando acabavam de soar que a pessoa não sabia se havia escutado direito (KAFKA, 1997, p. 11).

Nesse caso, vê-se claramente que a ambiguidade de Gregor se revela também na percepção auditiva, que reconhece "inconfundivelmente a voz antiga", pela qual, no entanto, se introduzia "um pipilar irreprimível de doloroso". Esse processo gradativo de construção do ator "inseto" e desconstrução do ator Gregor, em que o primeiro vai aos poucos substituindo o segundo, permanece ao longo de toda a obra. No decorrer da história, tomamos conhecimento de que ele perdera também a linguagem verbal, dificultando o processo de comunicação com a família. A partir de então, os pequenos gestos adquirem relevo e conduzem o sentido dentro do novo código que substitui a linguagem verbal na comunicação entre Gregor e os seus familiares. Por exemplo, ao menor sinal de entrada da irmã em seu quarto, Gregor se esconde debaixo do canapé, assim como o faz um animal domesticado que responde ao sinal de comando de seu dono. O código estabelecido entre ele e a irmã era apenas o giro lento da chave, na porta, advertindo Gregor de sua entrada: "[Gregor] tinha terminado tudo fazia tempo, e já estava deitado preguiçosamente no mesmo lugar, quando a irmã, para mostrar que ia voltar, virou lentamente a chave. Isso o sobressaltou de imediato [...] e ele correu de imediato para debaixo do canapé" (KAFKA, 1997, p. 38).

$\mathrm{Na}$ medida em que a metamorfose vai aos poucos lhe retirando por completo os traços humanos, Gregor vai sendo progressivamente objetualizado pela família, pois ela não dispõe de "tempo para se ocupar de Gregor mais que o absolutamente necessário" (KAFKA, 1997, p. 64). Em seguida, ele passa a não ser mais chamado nem mesmo pelo próprio nome "Gregor" - a faxineira recém-contratada pela família o chamava de "velho bicho sujo" 7 - e passa a ser simples objeto em meio a outros que são lançados em seu quarto, o qual se torna depósito de "muitas coisas que na verdade não se podiam vender, mas que também não se queriam jogar fora" e até mesmo da "lata de cinzas e a lata de lixo da cozinha" (KAFKA, 1997, p. 67). Vê-se que, aqui, a transformação no plano da figuratividade opera uma transformação actancial em Gregor, que passa da condição de sujeito para a de objeto e, posteriormente, para a de abjeto, quando é então abandonado completamente em seu quarto que se tornara depósito das coisas indesejáveis.

A partir de certo momento, Gregor passa a ser responsabilizado por todo o mal que se abate sobre a família e a ser visto consequentemente como o antissujeito disseminador da desgraça no ambiente familiar. E por essa razão, segundo as palavras de Grete, ele tem de ser totalmente afastado ("precisamos tentar nos livrar dele"):

\footnotetext{
7 "No começo ela [a faxineira] também o chamava ao seu encontro, com palavras que provavelmente considerava amistosas, como 'venha um pouco aqui, velho bicho sujo!' ou 'vejam só o velho bicho sujo!"” (KAFKA, 1997, p. 65).
} 
- Queridos pais - disse a irmã e como introdução bateu com a mão na mesa -, assim não pode continuar. Se vocês acaso não compreendem, eu compreendo. Não quero pronunciar o nome do meu irmão diante desse monstro e por isso digo apenas o seguinte: precisamos tentar nos livrar dele. Procuramos fazer o que é humanamente possível para tratá-lo e suportá-lo e acredito que ninguém pode nos fazer a menor censura (KAFKA, 1997, p. 74).

Ao convocar figuras díspares como "monstro" e "meu irmão", Grete o faz instituindo-as como sendo figuras contrárias e excludentes. Com isso, ela não consegue outra coisa senão instruir a família sobre as diferenças semânticas e actanciais que distinguem o Gregor-irmão do Gregor-monstro. Ou seja, ao lhe retirar por completo a função de sujeito e o traço semântico que o caracteriza como ser humano, ela dá início ao processo de triagem que resultará na exclusão do irmão. Além disso, a desgraça cada vez mais crescente que se abate sobre os Samsa desde a falência do pai, seguida posteriormente com a metamorfose e suas consequências na vida familiar, se polariza agora unicamente na figura de Gregor sob a versão particular de Grete. Todas as dificuldades pelas quais passava a família, suas inúmeras perdas e o temor que instaurara a tensão no ambiente familiar tornam-se, assim, fortes argumentos contra Gregor:

— Precisamos tentar nos livrar disso - disse então a irmã [...]. — Isso ainda vai matar a ambos, eu vejo esse momento chegando. Quando já se tem de trabalhar tão pesado, como todos nós, não é possível suportar em casa mais esse eterno tormento (KAFKA, 1997. p. 75).

Nas palavras de Grete ("Isso ainda vai matar a ambos"), ele se torna, portanto, o antissujeito ("monstro", "bicho") que põe toda a existência da família em perigo ("eterno tormento"). Não mais apenas como um abjeto que se deixa simplesmente à margem do ambiente familiar, Gregor é então visto na função de antissujeito, até mesmo ameaçador, visto que pode "matar a ambos" ou "ocupar o apartamento todo e nos fazer pernoitar na rua". Aos olhos de Grete, ele não é mais o irmão "Gregor"; é o culpado real da desgraça instaurada na família e, portanto, merece ser punido:

—É preciso que isso vá para fora - exclamou a irmã -, é o único meio, pai. Você simplesmente precisa se livrar do pensamento de que é Gregor. Nossa verdadeira infelicidade é termos acreditado nisso até agora. Mas como é que poderia ser Gregor? Se fosse Gregor, ele teria há muito tempo compreendido que o convívio de seres humanos com um bicho assim não é possível e teria ido embora voluntariamente. Nesse caso não teríamos irmão, mas poderíamos continuar vivendo e honrar a sua memória. Mas como está, esse bicho nos persegue, expulsa os inquilinos, quer certamente ocupar o apartamento todo e nos fazer pernoitar na rua (KAFKA, 1997, p. 75-76).

Aos poucos, essa versão particular da situação passa a ser inteiramente compartilhada também pelos pais ("- Ela tem mil vezes razão - disse o pai consigo mesmo") e Gregor é finalmente trancado dentro de seu quarto, "a porta [...] batida na maior pressa, travada e fechada a chave" (KAFKA, 1997, p. 77). Percebe-se, assim, que a transformação atorial, que se caracteriza, aqui, com a perda de identidade, só ocorre quando Gregor perde o próprio nome. Este era, para a família, o último traço humano que ainda lhe restava. Nesse caso, a perda do nome implica não apenas a perda de identidade ao nível do indivíduo, mas ao 
nível da espécie. É, portanto, somente agora que Gregor de fato se transformara definitivamente no "inseto monstruoso" que o narrador já indicava no primeiro parágrafo da novela. Mas um exame mais cuidadoso revela que Gregor ainda preservava alguns traços humanos, alguns até mesmo de modo acentuado, que o tornava ainda mais humano, por mais paradoxal que essa afirmação possa ser. Vejamos o trecho que relata os últimos instantes de vida de Gregor:

Logo descobriu que não podia absolutamente mais se mexer. Não se admirou com esse fato, pareceu-lhe antes pouco natural que até agora tivesse conseguido se movimentar com aquelas perninhas finas. No restante sentia-se relativamente confortável. Na realidade tinha dores no corpo todo, mas para ele era como se elas fossem ficar cada vez mais fracas e finalmente desaparecer por completo. [...] Recordava-se da família com emoção e amor. Sua opinião de que precisava desaparecer era, se possível, ainda mais decidida que a da irmã. Permaneceu nesse estado de meditação vazia e pacífica até que o relógio da torre bateu a terceira hora da manhã. Ele ainda vivenciou o início do clarear geral do dia lá do lado de fora da janela. Depois, sem intervenção da sua vontade, a cabeça afundou completamente e das suas ventas fluiu fraco o último fôlego [grifo nosso] (KAFKA, 1997, p. 78).

É possível reconhecer nesse parágrafo a presença de uma instância cognitiva e afetiva que orienta os atos de consciência de Gregor. O Gregor que se mostra aí não parece ser o mesmo Gregor alienado que encontramos no restante da obra. De fato, é nesse momento, próximo da morte, que ele eleva ao máximo a sua consciência humana ao fazer uma avaliação de sua própria condição ("Não se admirou com esse fato [...]", "Sua opinião [...]") e manifesta em pensamento seus sentimentos para com a família ("Recordava-se da família com emoção e amor"). Há também, nesse parágrafo, alguns traços de uma isotopia que parece convocar um discurso de resignação característico da doutrina estoica, segundo a qual a "felicidade radica na aceitação do destino, no combate contra as forças da paixão que produzem a intranquilidade. Ao resignar-se com o destino, o homem também se resigna com a justiça, pois o mundo é, enquanto racional, justo" (MORA, 2001, p. 914). Esses traços, disseminados por todo o parágrafo, se mostram mais salientes nos seguintes trechos: "Sua opinião de que precisava desaparecer era, se possível, ainda mais decidida que a da irmã", "estado de meditação vazia e pacífica", "Recordava-se da família com emoção e amor". Mas também os reconhecemos nas experiências estésicas do toque do sino que Gregor ouve soar na torre da igreja e da luz indicando "o início do clarear do dia", ambas as experiências assemelhando-se às que antecedem a cosmovisão do homem estóico num estado de epifania. Há, nesse sentido, um Gregor mais sensível e humano.

Essas observações nos fazem pensar que o julgamento que incide sobre Gregor, feito pela irmã, não partiu de uma avaliação rigorosa. Vê-se, portanto, que não é simples a situação criada pelo narrador kafkiano ao fornecer apenas ao leitor as condições para saber que havia não apenas um resíduo de ser humano por trás do "inseto monstruoso", mas um ser humano que amava a família e, pela própria condição, resignava-se perante o que o destino lhe reservara. O que ocorre aqui, na novela de Kafka, é que no espaço modal da enunciação são instalados vários simulacros e dispositivos cognitivos de apreensão do fenômeno da metamorfose. Esses simulacros se encontram nos discursos e nas avaliações dos atores, por exemplo, Grete, a mãe e o pai de Gregor, todos de algum modo conhecedores de algum aspecto de Gregor por meio daquilo que a fenomenologia de Husserl chama de "atos de 
consciência" ou "vivências da consciência" ${ }^{8}$, que são as atividades intencionais do sujeito do conhecimento, ou sujeito epistêmico, que deve interpretar e avaliar os objetos que lhe foram dados a exame. É importante ressaltar que são esses simulacros que vão, num primeiro momento, virtualizar os traços humanos de Gregor para depois excluí-lo por completo da categoria dos seres humanos, e num segundo momento substituí-los pelos traços semânticos que caracterizam o "inseto monstruoso", atualizando e, por fim, realizando definitivamente a figura do inseto.

A questão que gostaríamos de formular poderia sê-lo feita da seguinte maneira: como é possível que o julgamento de Grete acerca de Gregor passe da condição de juízo epistêmico (da ordem do crer-ser, correspondente ao valor modal da "certeza") para um enunciado modal próprio à modalidade alética do dever-ser (necessidade)? Essa questão é crucial, pois revela que Grete realiza um "salto" cognitivo enorme ao sancionar negativamente o irmão (as modalidades mencionadas fazem parte de quadros epistemológicos bem distintos: uma é da ordem do crer, ao passo que a outra, do dever).

A partir da estrutura modal epistêmica, formulada por Greimas e Courtés ([1983], p. 151), é possível recuperar o percurso cognitivo operado pela irmã de Gregor. Antes, porém, é preciso considerar que, logo depois da metamorfose, a família estava incerta quanto à identidade do filho. O próprio fato de conservarem-no isolado no quarto, dentro de casa, sustenta essa hipótese. Talvez, a primeira manifestação dessa incerteza quanto à condição de Gregor seja o desejo expresso da mãe em vê-lo: “- Deixem-me ver Gregor, ele é o meu filho infeliz! Vocês não entendem que eu preciso vê-lo?” (KAFKA, 1997, p. 47). O apelo da mãe ao protestar "ele é o meu filho infeliz" parece ser uma última tentativa da mãe em trazer de volta (atualizar) o "filho" cuja presença, depois da metamorfose, estava relegada apenas à virtualidade de algumas lembranças. Mesmo a permanência forçada de Gregor no quarto pode ser vista como uma etapa desse processo de virtualização, por meio do qual é concedida a ele uma espécie de aceitação restrita no espaço familiar. É, portanto, nessa condição de incerteza que se encontra a família até o episódio em que a irmã de Gregor lhe dá o veredicto final por meio de um percurso cognitivo que será apresentado a seguir.

Primeiro, Grete procura dissipar qualquer vestígio de Gregor na crença de seus pais e convencer a todos da certeza de estarem sustentando dentro de casa um "monstro". As palavras de Grete mostram, portanto, que é improvável que seja Gregor. Ela ainda adverte: "Você [pai] simplesmente precisa se livrar do pensamento de que é Gregor. Nossa verdadeira infelicidade é termos acreditado nisso até agora" [grifo nosso] (KAFKA, 1997, p. 76). Se Gregor não mais existia na realidade, agora era preciso retirá-lo, também, da virtualidade do "pensamento". Depois, ela ainda diz ser provável que Gregor ponha em risco a vida da família, colocando-se, também, como testemunha ("eu vejo"): “- Isso ainda vai matar a ambos, eu vejo esse momento chegando" [grifo nosso] (KAFKA, 1997, p. 76). Em seguida, Grete constrói sua argumentação fundamentada numa relação causal ("Se fosse Gregor, então...") para sustentar a certeza de que não é mais Gregor: "Se fosse Gregor, [então] ele teria há muito tempo compreendido que o convívio de seres humanos com um bicho assim não é possível e teria ido embora voluntariamente" (KAFKA, 1997, p. 75).

O percurso modal-cognitivo de Grete, que acabamos de apresentar, encontra-se dentro do quadro das modalidades epistêmicas (Cf. GREIMAS, [1983], p. 151), cuja estrutura modal é formada por uma modalidade do crer que sobredetermina um predicado existencial ou enunciado de estado. São essas modalidades que vão compor a competência cognitiva do

\footnotetext{
${ }^{8}$ Para maior compreensão do que sejam esses "atos de consciência" no pensamento de Husserl, ver: Bruce Bégout, Edmund Husserl, em Philippe Cabestan, Introduction à la phénoménologie, Paris, Ellipses, 2003, p. 1135.
} 
sujeito quando ele executa um fazer interpretativo e, em seguida, emite um juízo epistêmico acerca do objeto (que, como dissemos, pode ser um predicado existencial ou enunciado de estado). Nas narrativas, de modo geral, esse juízo epistêmico é feito normalmente por um destinador julgador (o sujeito epistêmico) ao interpretar as posições cognitivas formuladas por outro sujeito, envolvendo, portanto, dois actantes no processo interpretativo. O problema para o qual chamamos atenção, aqui, é que esses juízos de Grete são feitos sobre suas próprias posições cognitivas, pois ela subsume as duas funções. Sobre a posição cognitiva, tomada por ela, "Gregor é um monstro", ela emite o juízo "Se vocês acaso não compreendem, eu compreendo [que Gregor é um monstro]" (é preciso tomar aqui o predicado "compreender" no sentido de "ter certeza de", ou seja, de crer-ser). O problema se agrava, quando na questão "Mas como é que poderia ser Gregor?" (KAFKA, 1997, p. 76), se deixa entrever a voz de uma instância enunciativa que se vale de um predicado cujo valor modal é a "necessidade" (ou seja, é necessário que seja um monstro).

Notamos rapidamente que é na última etapa do percurso cognitivo de Grete, correspondente à modalidade alética, que reside toda a problemática em torno da questão, pois o valor modal "necessidade" tem validade absoluta. Nesse caso, a própria enunciação deixa entrever que há outro actante cognitivo, uma espécie de testemunha que se encontra num patamar discursivo superior ao do ator do enunciado e teria condições de emitir um juízo com validade mais absoluta acerca de Gregor, pois que teria acesso a um perfil privilegiado do objeto. Em termos fenomenológicos, diríamos que, para esse actante, há disponível um horizonte de significações mais extenso. Como já antecipamos momentos atrás, esse actante é o próprio leitor, actante cognitivo pressuposto pela enunciação. Somente a ele são dadas as condições de reconhecimento de ainda existir em Gregor um ser humano. Por meio de um procedimento que a língua permite, a recursividade, podemos dizer que ao leitor da $A$ metamorfose (1997) de Kafka é franqueado emitir um juízo sobre o juízo de Grete acerca de Gregor.

\section{Considerações finais}

As investigações fenomenológicas no campo da semiótica ainda são incipientes. Greimas, em Da imperfeição (1987), lançara algumas hipóteses que, sem dúvida, enriqueceram a teoria, na medida em que a significação passava a ser decorrente de um excesso do objeto e não mais da falta. Mas o universo de investigação do sentido que se abre com a fenomenologia parece ser inesgotável. Aqui apresentamos mais uma possibilidade de operacionalização não tanto dos conceitos fenomenológicos, mas de certo olhar fenomenológico que acompanha os procedimentos de construção de sentido de um texto. Ressaltamos também a particularidade do motivo da metamorfose na obra de Kafka, $A$ metamorfose (1997). Diferentemente da maioria dos textos em que reconhecemos haver a presença do motivo da metamorfose, apresentando-a no interior de uma narratividade mais conforme a teoria proppiana, na novela de Kafka o motivo é instalado como um acontecimento, sendo, portanto, delimitado diretamente no interior de um espaço modal da enunciação, num jogo dinâmico em que os participantes são atores do enunciado e actantes da enunciação. A partir das operações cognitivas que o modalizam como objeto de cognição e que antecedem à instauração do juízo, mostramos, finalmente, as operações discursivas que instruem a virtualização e até mesmo a destruição completa dos traços humanos de Gregor ao mesmo tempo em que atualizam o "inseto monstruoso" potencialmente presente no primeiro parágrafo da novela. 
CASA, Vol.8 n.2, dezembro de 2010

\section{Referências bibliográficas}

APEL, Karl Otto. La sémiotique transcendental et les paradigmes de la Prima Philosophia. Revue de Métaphysique et de Morale. 92e. Année, $\mathrm{n}^{\mathrm{o}}$ 2, Avril-Juin. Paris: Armand Colin, 1987, p. 147-163.

BERTRAND, Denis. Caminhos de semiótica literária. Trad. Grupo CASA. Bauru, SP: Edusc, 2003.

CAMUS, Albert. A esperança e o absurdo na obra de Kafka. In: O mito de Sísifo. Rio de Janeiro: Record, 2005.

GREIMAS, Algirdas Julien. Sémantique structurale. Paris: PUF, [1966] 2007. De l'imperfecion. Périgueux, Pierre Fanlac, 1987. ; COURTÉS, Joseph. Dicionário de semiótica. São Paulo: Cultrix, [1983].

HUSSERL, Edmund. A crise da humanidade europeia e a filosofia. Porto Alegre: EDIPUCRS, 2008. . Recherches logiques I - Prolégomènes à la logique pure. Paris: PUF, [1913] 2002.

KAFKA, Franz. A metamorfose. São Paulo: Companhia das Letras, 1997.

MERLEAU-PONTY, Maurice. O corpo como expressão e a fala. In: Fenomenologia da percepção. São Paulo: Martins Fontes, [1945] 1999.

MORA, José Ferrater. Dicionário de Filosofia - Tomo II. São Paulo: Edições Loyola, 2001. OVÍDIO. As metamorfoses. Trad. Bocage. São Paulo: Hedra, 2000.

SILVA, Ignacio Assis. Figurativização e metamorfose: o mito de Narciso. São Paulo: Ed. da UNESP, 1995. (Prismas).

ZILBERBERG, Claude. Précis de grammaire tensive. Tangence, $\mathrm{n}^{\circ}$ 70, 2002. . Eléments de grammaire tensive. Limoges: PULIM, 2006. 